\title{
Psycho-Oncology
}

Journal of the Psychological, Social and

Behavioral Dimensions of Cancer

\section{Cancer-related cognitive impairment in survivors of adolescent and young adult cancer: A scoping review}

\begin{tabular}{|c|c|}
\hline Journal: & Psycho-Oncology \\
\hline Manuscript ID & PON-21-0477 \\
\hline Wiley - Manuscript type: & Review \\
\hline $\begin{array}{r}\text { Date Submitted by the } \\
\text { Author: }\end{array}$ & 28-May-2021 \\
\hline Complete List of Authors: & $\begin{array}{l}\text { Vizer, Lisa M.; University of North Carolina at Chapel Hill School of } \\
\text { Medicine } \\
\text { Piepmeier, Aaron T.; Elon University } \\
\text { Mikles, Sean P.; University of North Carolina Lineberger Comprehensive } \\
\text { Cancer Center }\end{array}$ \\
\hline Keywords: & $\begin{array}{l}\text { Cancer, oncology, cancer survivors, adolescent, young adult, cognitive } \\
\text { dysfunction, chemotherapy-related cognitive impairment, review }\end{array}$ \\
\hline
\end{tabular}

\section{SCHOLARONE Manuscripts}




\title{
Cancer-related cognitive impairment in survivors of adolescent
}

\section{and young adult cancer: A scoping review}

\author{
Lisa M. Vizer, $\mathrm{PhD}^{1}$ \\ Aaron T. Piepmeier, PhD, MS² \\ Sean P. Mikles, PhD, MPH \\ ${ }^{1}$ School of Medicine, University of North Carolina, Chapel Hill, NC, USA \\ ${ }^{2}$ Elon University, Elon, NC, USA \\ ${ }^{3}$ Lineberger Comprehensive Cancer Outcomes Program, University of North Carolina, Chapel Hill, NC, USA
}

\section{Acknowledgements}

Dr. Vizer was supported in part by the National Center for Advancing Translational Sciences, National Institutes of Health (NIH), through Grant Award Number UL1TR002489. Dr. Mikles is supported by the NIH National Cancer Institute National Research Service Award sponsored by the Lineberger Comprehensive Cancer Center at the University of North Carolina (T32 CA116339). The content is solely the responsibility of the authors and does not necessarily represent the official views of the NIH.

\section{Conflict of Interest Statement}

No conflict of interest has been declared by the authors.

\section{Abstract}

Objectives: Cancer-related cognitive impairments (CRCI) are common after treatment and could have important repercussions for adolescent and young adult (AYA) survivors diagnosed between ages 15 and 39. However, most research focuses on younger or older survivors so we know relatively little about $\mathrm{CRCl}$ among $\mathrm{AYA}$ cancer survivors. Here we review the research on $\mathrm{CRCl}$ among survivors of AYA cancer to determine prevalence, associated factors, and ongoing impact.

Methods: In December 2020 we performed a systematic search in MEDLINE, Web of Science, PsycInfo, CINAHL, EMBASE, and Cochrane Central Register of Controlled Trials to identify peer-reviewed English language articles describing original research with survivors of AYA cancer having at least one outcome concerning cognition. We 
screened 4090 articles and 35 met eligibility criteria. Guided by the PRISMA-ScR Checklist, we extracted information, assessed study quality, organized articles by study design, identified factors associated with CRCl, and identified ongoing impacts of $\mathrm{CRCl}$.

Results: Most studies were cross-sectional surveys and interviews with some longitudinal and neurocognitive assessment studies, one brain imaging study, and one intervention study. Weighted mean prevalence of CRCl was 38.4\%. Factors associated with $\mathrm{CRCl}$ included older age, female gender, higher dose chemotherapy, and comorbidities. Ongoing impacts of $\mathrm{CRCl}$ included impaired role functioning, financial toxicity, and unmet needs. However, the intervention study had encouraging results for improving cognition and functioning.

Conclusions: This review of literature on $\mathrm{CRCl}$ in survivors of AYA cancer shows a need for longitudinal, imaging, and intervention studies. Digital health technology is recommended for research and intervention implementation.

Keywords: Cancer, oncology, cancer survivors, adolescent, young adult, cognitive dysfunction, chemotherapyrelated cognitive impairment, review

\section{Background}

In the United States, about 89,500 adolescents and young adults (AYAs) - those between ages 15 and $39^{1}$-were diagnosed with cancer in $2020^{2}$. The impact of cancer on cognition is a concern for many of these survivors as the disease and its treatments disrupt a critical period of rapidly developing behavioral and emotional skills and social role ${ }^{3}$. Although cancer survivors regularly report cognitive issues after treatment, these needs are often unaddressed ${ }^{4}$. The literature on cognitive function specifically in AYA cancer survivors is sparse, making it difficult to provide evidence-based assistance. This review aims to characterize the evidence for cancer-related cognitive impairments (CRCI) in AYAs so that providers can deliver appropriate support during survivorship.

\section{Cognition and cancer}

A growing evidence base supports the lasting impact of cancer and its treatment on cognitive function ${ }^{5-8}$. Cognitive functions typically affected are memory, attention, executive function, and processing speed ${ }^{9}$, resulting in negative impacts on quality of life ${ }^{10}$. Reported prevalence of $\mathrm{CRCl}$ ranges widely from 6 to $68 \%$ in children ${ }^{6}$ and from 17 to 
$75 \%$ in adults ${ }^{11}$. Some factors thought to influence measures of prevalence are the cancer diagnosis and treatment, cognitive assessment methods, and $\mathrm{CRCl}$ definitions.

\section{Cancer diagnosis and treatment}

Some $\mathrm{CRCl}$ is attributable to cancer itself. Central nervous system (CNS) cancers are most likely to result in $\mathrm{CRCI}$ due to a direct effect on brain tissue ${ }^{8}$, but non-CNS cancers are also thought to contribute to $\mathrm{CRCl}$; most of the research is with female breast cancer survivors ${ }^{8,9}$. Some research suggests that non-CNS cancers affect cognition even prior to diagnosis ${ }^{8}$, while other studies suggest that differences in cognition for cancer patients may be due to post-traumatic stress from receiving the cancer diagnosis or selection bias in research studies ${ }^{12,13}$. Although colloquial references such as "chemo-brain" or "chemo-fog" suggest that chemotherapy is primarily responsible for $\mathrm{CRCl}^{8,9}$, evidence indicates associations between $\mathrm{CRCl}$ and other therapies such as radiation or surgical resection as well ${ }^{8}$.

\section{Cognitive assessment}

Cognitive function can be assessed using either objective neuropsychological batteries, which measure performance in specific domains, or subjective patient self-reports, which give insights into the patient's experience of their cognitive capacity. The outcomes differ, with objective impairment being less prevalent than subjective impairment in cancer survivors ${ }^{14}$. Evidence suggests that subjective cognitive deficits are strongly correlated to depression, anxiety, or fatigue and only weakly correlated to objectively measured cognitive impairment ${ }^{15}$.

There is also very little concordance in the assessments researchers use, hindering comparison between studies. In 2011, the International Cognition and Cancer Task Force (ICCTF) issued a recommended objective assessment battery that takes about 35 minutes to complete with supplemental tests that add 10 to 90 minutes each ${ }^{16}$. In 2021, the Cancer Neuroscience Initiative Patient-Reported Outcomes Working Group issued a recommendation for the subjective Patient-Reported Outcomes Management Information System (PROMIS) Cognitive Function Short Form $8 a^{17}$. 


\section{Definition of cognitive impairment}

In addition to the measures, the criteria for cognitive impairment vary from study to study. The ICCTF recommends that $\mathrm{CRCl}$ be defined as scoring 1.5 standard deviations below the mean on two or more neurcognitive assessments or 2 standard deviations below the mean on one neurocognitive assessment ${ }^{16}$, but this definition isn't universally adopted. The lack of standardization inevitably impacts the prevalence reported in the literature. Schilder et al. ${ }^{18}$ found that prevalence ranged from $1 \%$ to over $45 \%$ depending on $\mathrm{CRCl}$ criteria and reference group.

\section{Considerations for adolescents and young adults}

Although AYAs are diagnosed with cancer at about eight times the rate of children age 14 and under, much of the evidence providers reference to manage late effects in AYAs comes from the literature on survivors of childhood cancer ${ }^{19,20}$. However, studies show that AYAs are not just "big children" and providers need a reliable evidence base to deliver appropriate care to this age group ${ }^{20}$.

The adolescent and young adult years are a critical period of physical, cognitive, social, and emotional development, and a cancer diagnosis during this period can have a lasting impact on the patient's entire life course $^{3}$. Evidence on brain development indicates that the frontal lobe and amygdala mature and develop into the 20 s and the hippocampus begins to decline after age $30^{21}$, and each is more vulnerable to stress during those times. Particularly during adolescence, exposure to highly stressful or traumatic events such as life-threatening illness is a predisposing factor for developing conditions such as major depressive disorder and anxiety-related disorders ${ }^{22}$. Cancer and its treatment can also disrupt the important developmental milestones of adolescence and early adulthood, including those related to cognition, and change educational and career trajectories ${ }^{9}$. Further compounding these impacts, adolescents and young adults often do not have the social or material support that is more available to patients who are older or younger ${ }^{23}$. All of these factors can affect cognitive health and have lasting impacts beyond adolescence or young adulthood. 


\section{Objectives}

In an effort to organize the evidence concerning $\mathrm{CRCl}$ in survivors of $\mathrm{AYA}$ cancer, this review collates the original research on cognitive symptoms, identifies gaps, and specifies priorities for future research. We aim to answer the following research questions:

(1) What is the evidence for prevalence of $\mathrm{CRCl}$ among survivors of AYA cancer?

(2) What is the evidence for the factors associated with $\mathrm{CRCl}$ among survivors of AYA cancer?

(3) What is the evidence for the ongoing impacts of $\mathrm{CRCl}$ on survivors of AYA cancer?

\section{Method}

\section{Overview}

Using the PRISMA-ScR scoping review methods ${ }^{24}$, we conducted a scoping review to organize the original research on $\mathrm{CRCl}$ in survivors of AYA cancers.

\section{Inclusion Criteria}

Inclusion criteria were: (1) full-text article in a peer-reviewed venue, (2) English language, (3) original research with survivors of cancer diagnosed between the ages of 15 and 39 or stratified by age, and (4) at least one measurement concerning cognition. To incorporate the range of research on AYA survivors, we included research with both qualitative and quantitative measurements. For studies including participants outside of the 15 to 39 age range, we included articles if results were reported by age group or if over half of the participants were age 15 to 39 at diagnosis. Considering the paucity of research on AYAs, we made this decision in an attempt to be as inclusive as feasible. We excluded studies examining only central-nervous system cancers since $\mathrm{CRCl}$ are expected and more severe for these survivors. 


\section{Data Sources and Search Strategies}

We completed a systematic search in December 2020 for relevant articles indexed in Pubmed, Web of Science, PsycINFO, Cumulative Index of Nursing and Allied Health Literature (CINAHL), Excerpta Medica dataBASE (EMBASE), and the Cochrane Central Register of Controlled Trials (CENTRAL). Search terms included phrases indicating adolescent and young adult age, cancer survivor, and cognitive impacts. We also searched several phrases that are associated with cognition in cancer survivors such as "impairment", "late effects", and "unmet needs." An example search string for PubMed is:

("adolescent"[All Fields] OR "young adult"[All Fields]) AND ("neoplasms"[MeSH Terms] OR "neoplasms"[All Fields] OR "cancer"[All Fields]) AND (("cognition"[MeSH Terms] OR "cognition"[All Fields]) OR "late effects"[All Fields] OR "unmet needs"[All Fields])

We also reviewed references of screened articles for additional literature.

\section{Procedure}

Our search yielded 4090 articles. Using Covidence software to manage the review process, we removed 1349 duplicates then screened 2741 abstracts. Two people independently screened each abstract and conflicts were reconciled through consensus with one author (LMV) being the final arbiter. We then screened 290 full-text articles in the same manner resulting in 35 articles for synthesis. The PRISMA flow diagram for the screening process is in Figure 1.

Figure 1: PRISMA flow diagram

\section{Extraction and Charting of Results}

We extracted information related to the objectives of the review: study methods, participant details, study measures, $\mathrm{CRCl}$ findings, and any results concerning prevalence, associated factors, or ongoing impacts of $\mathrm{CRCl}$. Extracted information was independently verified by a research assistant and articles were organized according to methods and findings. Prevalence of $\mathrm{CRCl}$ was calculated through weighted means and medians across the studies. Based on the extracted results, two researchers independently formed themes around the factors associated with 6 
and impact of $\mathrm{CRCl}$, and theme descriptions were harmonized through discussion. We appraised study quality using the Mixed Methods Appraisal Tool ${ }^{25}$ due to the inclusion of both quantitative and qualitative data.

\section{Results}

Evidence from the 35 included articles is organized in Appendix 1 by research method (quantitative, mixed, or qualitative) and includes study and participant details, measures of cognition, significant cognitive outcomes, and quality appraisal. Twenty-two studies used quantitative methods, four employed mixed methods, and nine utilized qualitative methods.

First, we characterize the extent of research and methods used. Next, we report the weighted average prevalence, associated factors, and ongoing impacts of $\mathrm{CRCl}$ among AYA cancer survivors.

\section{Extent of research}

Publications per year

Figure 2 shows the yearly trend of publications on AYA CRCI. We see higher interest in 2012 and 2013 followed by a 3-year lull and a recent upswing starting in 2017.

Figure 2: Articles published per year on $\mathrm{CRCl}$ in AYA cancer survivors

\section{Types of research}

\section{Data collection}

Articles described a wide range of data collection methods including surveys, interviews, cognitive assessments, focus groups, brain imaging, and intervention. Five articles reported results of longitudinal studies and the other 30 reported results of cross-sectional studies. Figure 3 shows data collection methods by cross-sectional and longitudinal designs. Some studies used more than one method.

Figure 3: Data collection methods used

7 


\section{Cognitive measures}

For the 26 quantitative and mixed method studies, validated self-report instruments were used in $66 \%$ of studies, standard neuropsychological assessments in about 9\%, and investigator-developed instruments in 25\% (Figure 4). Of the longitudinal studies, four used self-reported outcomes ${ }^{36,40,45,50}$ and one utilized neurocognitive assessments $^{48}$. Qualitative studies did not specifically assess cognition, instead allowing cognitive concerns to emerge organically, so those are not included in the figure.

Figure 4: Cognitive measures used in quantitative and mixed methods studies

Two studies used both objective and subjective cognitive measures ${ }^{39,47}$. Nugent et al. ${ }^{39}$ found no significant difference between survivors and controls on objective measures but did find small and medium effect sizes and a significantly higher rate of subjective memory problems among survivors. Trachtenburg et al. ${ }^{47}$ reported that survivors scored significantly lower than controls on multiple cognitive measures and that objective and subjective measures were correlated.

\section{Prevalence of $\mathrm{CRCI}$ in AYAs}

We included 10 articles in the calculation of mean prevalence weighted by number of participants (Table 1). One article reported prevalence based on validated objective neurocognitive assessments while the rest relied on selfreports. For articles reporting more than one prevalence we used the most conservative number. We calculated a median prevalence of $49 \%$ and a weighted mean of $38.4 \%$. This is consistent with other estimates of around $35 \%$ for ongoing cognitive problems after cancer treatment ${ }^{5,8}$. We excluded two studies from our calculations because we could not determine an estimate of prevalence of cognitive problems for AYAs (noted in Table 1).

Table 1: Prevalence of CRCI reported per article

\begin{tabular}{|c|l|l|c|}
\hline \multicolumn{1}{|c|}{ Article } & \multicolumn{1}{|c|}{ Prevalence } \\
\hline Objective assessment & 11 no chemotherapy & $0 \%$ no chemotherapy & \multicolumn{1}{|c|}{ Weighted Mean } \\
\hline Wefel et al. ${ }^{48}$ & 23 low chemotherapy & $52 \%$ low chemotherapy & $38.4 \%$ \\
& 28 high chemotherapy & $67 \%$ high chemotherapy & \\
\hline
\end{tabular}




\begin{tabular}{|c|c|c|c|}
\hline \multicolumn{3}{|c|}{ Self-report - included in prevalence calculation } & \multirow{2}{*}{$\begin{array}{l}\text { Median } \\
49 \%\end{array}$} \\
\hline Prasad et al. ${ }^{41}$ & 1054 survivors & $\begin{array}{l}\text { 13.9\% impaired task efficiency } \\
21.6 \% \text { impaired memory }\end{array}$ & \\
\hline Ketterl et al. ${ }^{35}$ & 872 survivors & $54.2 \%$ task interference & \\
\hline Szalda et al. ${ }^{46}$ & 611 survivors & $56 \%$ neurocognitive concerns & \\
\hline Jones et al. ${ }^{33}$ & 575 survivors & $49 \%$ cognitive changes & \\
\hline Rey et al. ${ }^{42}$ & 222 survivors & $>=36.5 \%$ at each timepoint & \\
\hline Stevens et al. ${ }^{61}$ & 55 survivors & $46 \%$ "brain fog" & \\
\hline McLoone et al. ${ }^{59}$ & 19 survivors & $50 \%$ student-reported & \\
\hline Armin et al. ${ }^{49}$ & 19 survivors & $47 \%$ cognitive impact & \\
\hline Fauske et al. ${ }^{56}$ & 18 survivors & $83 \%$ some cognitive impact & \\
\hline \multicolumn{3}{|c|}{ Self-report - not included in prevalence calculation } & Exclusion reason \\
\hline Huang et al. ${ }^{30}$ & 604 survivors & $32 \%$ cognitive concerns & $\begin{array}{l}\text { Reported influence of age } \\
\text { but did not stratify results }\end{array}$ \\
\hline Vetsch et al. ${ }^{52}$ & 42 survivors & 69\% interviewer-rated impairment & $\begin{array}{l}\text { Rating included physical and } \\
\text { cognitive impairments }\end{array}$ \\
\hline
\end{tabular}

\section{Factors associated with CRCI in AYAs}

Structural differences in the brain and individual factors such as treatment type, cancer type, age, gender, and comorbidities are associated with $\mathrm{CRCl}$ in AYAs.

\section{Structural differences in the brain}

In the single imaging study, Apple et al. ${ }^{26}$ found that, compared to controls, survivors show more inward hippocampal deformation, worse cognitive functioning, and lower episodic memory test scores, which is consistent with evidence that the hippocampus begins to decline after age 30 and is more vulnerable to stress or disease during that time ${ }^{21}$. 


\section{Cancer Treatment Type}

Five studies investigated an association between cognitive issues and cancer treatment type. Two examined the role of chemotherapy with survivors of testicular cancer ${ }^{43,48}$, two examined the impact of chemotherapy with or without radiotherapy on survivors of Hodgkin lymphoma ${ }^{36,47}$, and one examined the effects of chemotherapy, radiation, and surgery stratified by age and cancer type ${ }^{35}$. Skoogh et al. ${ }^{43}$, Wefel et al. ${ }^{48}$, Trachtenberg et al. ${ }^{47}$, and Ketterl et al. ${ }^{35}$ reported associations between chemotherapy and cognitive issues for all cancer types, although some cancers showed lower risk than others. Ketterl et al. ${ }^{35}$ also found a link between cognitive issues and radiation treatment for breast cancer, as well as a link between surgery and cognitive issues for less common cancers, including sarcoma, germ cell tumors, skin cancer and brain tumors. In contrast, Kreissl et al. ${ }^{36}$ found no effect of treatment type, including chemotherapy, on cognitive outcomes for Hodgkin lymphoma.

Studies also found 'dose-response' relationships with higher levels of chemotherapy being associated with increased reports of cognitive difficulties. Skoogh et al. ${ }^{43}$ and Trachtenberg et al. ${ }^{47}$ found dose-response relationships with the number of chemotherapy cycles, while Wefel at al. ${ }^{48}$ noted the relationship with chemotherapy dosing. However, researchers could not determine whether decline was due to the dose or the specific chemotherapy regimen.

Ketterl et al. ${ }^{35}$ found that breast cancer survivors who had radiation or chemotherapy had higher mental impairment at work, which was also found with survivors of cancers other than breast cancer, leukemia, lymphoma or thyroid cancer who underwent chemotherapy or surgery.

\section{Cancer Type}

A handful of studies examined the impact of cancer type on cognition. Husson et al. ${ }^{32}$ found that worse cognitive outcomes were associated with having had leukemia, Hodgkin's lymphoma, or a cancer with a lower survival rate, while Prasad et al. ${ }^{41}$ found that survivors of lymphoma and sarcoma were at lower risk of neurocognitive problems than survivors of leukemia. Nowe et al. ${ }^{38}$ found that breast and gynecological cancer survivors reported higher cognitive fatigue while testicular cancer survivors reported lower cognitive fatigue. Smith et al. ${ }^{44}$ found no association between cancer type and work or school functioning. 
Most studies that examined age and cognitive impairments found that older age was associated with higher levels of impairment $31,36,45,46,56$. However, one article reported that younger survivors had more cognitive impairment ${ }^{48}$, one found that younger survivors reported worse functioning ${ }^{44}$, and one found no difference in cognitive function between older and younger survivors ${ }^{28}$.

\section{Gender}

In the studies that compared outcomes by gender, all reported worse cognitive outcomes for female survivors ${ }^{31,32,36,38}$. Kreissl et al. ${ }^{36}$ found that women reported higher cognitive deficit at all timepoints in their study. Husson et al. report that female AYA lymphoma survivors scored significantly worse on cognitive functioning compared to male survivors ${ }^{31}$, and female AYA survivors of any cancer scored significantly higher on the negative IOC summary scale and cognitive function subscale compared to male survivors ${ }^{32}$. Higher cognitive fatigue was also associated with being female in the study from Nowe et al. ${ }^{38}$.

\section{Comorbidities}

Worse cognitive outcomes were often associated with comorbid conditions, most often fatigue and mental illness. Husson et al. ${ }^{31,32}$ found that worse cognitive function was associated with having physical fatigue or having two or more comorbid health conditions such as diabetes or asthma. Similarly, Nowe et al. ${ }^{38}$ report and association between cognitive fatigue and having other health conditions.

Several articles reported that high physical fatigue and low cognitive function are comorbid and some suggest that they may be tightly coupled $31,32,39,45$. Husson et al. ${ }^{31,32}$, Kreissl et al. ${ }^{36}$, and Nugent et al. ${ }^{39}$ report correlations between worse perceived cognitive function and physical fatigue. Furthermore, Stadtbaeumer et al. ${ }^{45}$ showed that improvements in cognition reduced physical fatigue more than reductions in physical fatigue improved cognition. In contrast, Trachtenberg et al. ${ }^{47}$ found that although both physical fatigue and cognitive issues were common, they were not associated with each other in their sample of Hodgkin lymphoma survivors. 
Mental illness is common in cancer survivors ${ }^{62}$ and several articles in this review reiterated that conclusion ${ }^{33}$, but some went further to investigate the association between mental and cognitive health. Husson et al. ${ }^{31,32}$, Nugent et al. ${ }^{39}$, and Rey et al. ${ }^{42}$ all found correlations between cognitive problems and symptoms of depression and/or anxiety. Furthermore, Kreissl et al. ${ }^{36}$ found that worse cognitive function was strongly correlated with worse emotional function both 2 and 5 years after treatment.

\section{Ongoing impacts of $\mathrm{CRCl}$ in AYAs}

After treatment, cognitive issues have an ongoing impact on survivors' lives. We first describe the contextual evidence contributed by qualitative and mixed methods studies. Next, we examine the reported ongoing consequences associated with reduced cognitive function, and discuss the results of one intervention study designed to assess ability to mitigate ongoing difficulties in survivorship.

\section{Lived experience and characterization of cognitive function}

The survivor voice comes through in the mixed method and qualitative studies, giving powerful context for the results from the quantitative measures. Possibly due to a perceived lack of preparation for cognitive issues in survivorship ${ }^{51}$, survivors feel "overwhelmed" and "surprised" by the impact of changes in cognition ${ }^{53,63}$. They indicate a sense of $\operatorname{loss}^{58}$, experience difficulty adjusting to changes ${ }^{60}$, report "forgetting" or difficulty "keeping up $^{\prime 40}$, and find that cognitive issues are often more difficult for them to handle than some other symptoms because they are "invisible" 55. Participant described frustration with their concentration problems, with one saying that "I [lose] my train of thought like immediately." 52 Survivors also expressed a mismatch between their initial expectations of what their cognitive abilities would be and the poorer reality that they experienced later ${ }^{50}$.

\section{Role Functioning}

By far the most common theme across articles was that cognitive complaints are associated with difficulties in role functioning $27,35,39,41,44,50,52-59$. Survivors commonly reported worse concentration, memory, and attention $^{33,34,40,44,47,52,53,58}$ and were concerned about the negative impacts of these deficits on employment and education $27,39,40,47,53,58,59$. Husson et al. ${ }^{31,32}$ showed that worse cognitive function was associated with being 
unemployed. Unemployment was associated with self-reports of impaired task efficiency ${ }^{41}$ and with lower education levels ${ }^{42}$ in the AYA population.

However, a substantial proportion of survivors who report worse cognition after treatment are able to return to work or school. Parsons et al. ${ }^{40}$ report that over $72 \%$ of those either working or in school full-time prior to diagnosis returned to work or school even though $30 \%$ still endorsed problems with "paying attention" and $28 \%$ reported troubles "keeping up with work or studies." However, only $34 \%$ of those who worked or were in school part-time had returned to that level. Cheng et al. ${ }^{27}$ found that, compared to controls with similar backgrounds and jobs, cognitive symptoms at work were related to lower quantity, quality, and timeliness of completed work. Ketterl et al. ${ }^{35}$ found that breast cancer survivors treated with chemotherapy or radiation had more cognitive problems at work.

Ongoing financial problems may also be related to an association between cognitive problems and unemployment or difficulties in the workplace or school. Nowe et al. ${ }^{38}$ found that worse cognitive fatigue is associated with worse financial problems and Kreissl et al. ${ }^{36}$ determined a moderate correlation between worse cognitive function and worse financial health at both 2 and 5 years after treatment.

\section{Quality of life}

Several studies reported lower quality of life related to cognitive problems for AYA survivors ${ }^{30,31,36,42,50,56}$. Husson et al. ${ }^{31}$ surveyed lymphoma survivors and age- and gender-matched controls and found that survivors reported significantly worse scores in the cognitive domain of a health-related quality of life measure. In interviews with survivors, Fauske et al. ${ }^{56}$ found that participants with pronounced cognitive difficulties expressed that their lives had completely changed and that they were struggling to cope. Huang et al. ${ }^{30}$ found that higher levels of cognitive disturbance was associated with significantly lower quality of life.

In a longitudinal analysis, Kreissl et al. ${ }^{36}$ report that worse cognitive function is correlated with worse healthrelated quality of life in most domains from baseline through 5 years after treatment. Related to these findings, Rey et al. ${ }^{42}$ advise that since reports of cognitive impairment are common and affect quality of life, long-term complaints of cognitive impairment deserve greater consideration than they are currently afforded. 


\section{Unmet information and support needs}

Survivors often expressed that needs around cognitive issues were unmet $33,34,51,54,60,61$. Jones et al. ${ }^{33}$ found that only $41 \%$ of survivors with cognitive concerns sought help and $47 \%$ of those experienced difficulty finding help. Similarly, Stevens et al. ${ }^{61}$ found that although $46 \%$ of participants wished for support in dealing with "brain fog," fewer than $5 \%$ were actually offered support. AYA survivors were also disappointed in the lack of resources and support they received ${ }^{55}$ and they specifically want better access to cognitive assessment and rehabilitation resources ${ }^{54}$.

Rehabilitation

Although survivors can experience difficulty obtaining help with cognitive problems, we were encouraged by the positive results of the intervention study from Hauken et al. ${ }^{50}$. The authors tested a rehabilitation program for AYA cancer survivors with 20 participants and demonstrated a significant improvement in cognitive function from baseline through the end of the program. Importantly, those improvements were sustained during the follow-up period. Although cognitive function did not reach the level of the normative group, the study shows that declines can be somewhat mitigated or reversed. Furthermore, participants expressed high satisfaction with the program, high achievement of program goals, and high adherence to the program. They also recognized that they had learned new skills, gained new control, and could apply the skills and control in an ongoing rehabilitation process.

\section{Discussion}

The literature indicates that cancer-related cognitive symptoms are real and are challenging for survivors to manage. Although some survivors are able to obtain help with cognitive issues, most say that their needs are not adequately met. That lack of support can potentially complicate resumption of education and career and contribute to financial toxicity. 


\section{Cognitive Measures}

Perhaps the biggest issue inhibiting progress in this area is the lack of consistency in cognitive measures. The studies in this review used 12 different published scales, three different cognitive batteries, and several investigator-generated scales. This emphasizes the absence of a gold standard for assessing cognition in the cancer survivor population and makes comparisons and meta-analyses difficult. The assessment battery recommended by the ICCTF is appropriate for clinical use, but may be too time-intensive for research purposes. The most common instrument used in in this review, the subjective EORTC QLQ-C30, averages about 11 minutes for administration as compared to the base 35 minutes required by the ICCTF battery. However, objective and subjective assessments appear to measure different constructs with objective assessments measuring performance and subjective assessments giving insight into the patient's experience. Although objectively measured impairment is less prevalent than subjectively measured impairment ${ }^{14}$, the possible correlation between objective and subjective cognitive assessments reported by Trachtenberg et al. ${ }^{47}$ implies that clinicians may at least be able to use selfreport measures for screening rather than referring the bulk of survivors for expensive and time-consuming objective cognitive assessments.

Results from individual studies are likely to be highly dependent on the assessment used, the diagnoses and treatments included in the sample, as well as the sampling method, further complicating direct comparisons between studies. However, it is clear that a sizable portion of AYAs consider themselves to have impaired cognition 
compared to their capabilities prior to cancer and in all studies comparing prevalence between survivors and a control group, AYA survivors reported higher levels of cognitive issues ${ }^{30,33,41}$. Survivors often perceive cognitive problems although objective cognitive assessments show function within norms. This phenomenon may occur for several reasons (see ${ }^{15}$ for a comprehensive treatment), including that the decline may be too subtle for objective assessments to detect or that prior functioning was above norms. Furthermore, unlike people experiencing cognitive declines due to dementia or aging, AYA survivors are usually able to offer insight concerning their own functioning and reliably report their experiences. Many objective measures currently available were not developed to detect subtle decline ${ }^{64}$ and that problems not detected by objective measures are no less real or worrisome to those experiencing them ${ }^{17}$.

\section{Terminology}

The words articles use to refer to cancer-related cognitive impairment are inconsistent. Some articles discuss specific cognitive domains, including attention, concentration, thinking, or memory, while others use more colloquial terms, such as "chemo-fog" 58 , "brain fog" 61 , and "chemo brain"60. A lack of precise and common terminology in reporting makes it difficult to readily identify all articles that investigate cancer-related cognitive impairments. Qualitative studies illustrate that many survivors think of chemotherapy as primarily contributing to cognitive issues when they use phrases like "chemo brain"60 and "chemo- fog"58. However, chemotherapy seems to be only one of several factors involved in developing $\mathrm{CRCl}$, and such language may reveal a problematic bias by attributing cognitive issues only to chemotherapy.

\section{Comorbidities}

Many articles examine comorbidities as a factor affecting function in survivors and one of the comorbidities included is often impaired cognitive function. However, articles commonly report the number of comorbidities without specifying frequencies of individual comorbidities. A variation is articles that examine "unmet needs" or "late effects", one of which is often impaired cognitive function, but also do not specify frequency of particular needs or late effects. As with a lack of common cognitive measures, this lack of specificity makes comparisons and meta-analyses difficult and impedes investigation of relationships among comorbidities, needs, and late effects. 


\section{Participant ages}

Studies often include AYAs in their samples but do not stratify by age or analyze age groups separately. However, stratification or grouping by $\mathrm{NCl}$-defined age groups is important to identifying differences attributable in part to developmental differences between those age groups. It would also be helpful for articles to note age at diagnosis, age at study, and time since end of active treatment.

\section{Longitudinal studies}

Only five of the 35 articles in this review reported results of longitudinal studies. Although cross-sectional studies offer important insights, a relative lack of longitudinal studies hampers our ability to characterize the nature and trajectory of cognitive issues for AYA cancer survivors over time.

\section{Clinical Implications}

Based on the review of research on $\mathrm{CRCl}$ in survivors of $\mathrm{AYA}$ cancer, we have several recommendations for future research.

Well-characterized participant samples and control groups

In addition to specifying treatment regimen, cancer type, gender, age at diagnosis, time since end of active treatment, and comorbidities, studies of cognitive function should characterize risk factors associated with lower cognitive function such as PTSD, fatigue, and childhood trauma and stress $7,21,65,66$. This is particularly important as PTSD and fatigue are highly prevalent in AYA cancer survivors. Studies with well-characterized samples will help us better identify relationships among those characteristics in terms of impact on cognition.

Standard cognitive measures

Researchers need a battery of objective and subjective measures built around a brief core general assessment supplemented with recommendations for tests in specific domains as needed. This approach would institute a usable standard that enables researchers to assemble batteries that meet study objectives as well as time and 
resource constraints. To further support meta-analyses and comparison between studies, articles should also report subscale scores in addition to composite scores (ex. cognitive domain of EORTC QLQ-C30).

\section{Longitudinal research}

The lack of longitudinal studies is a crucial barrier to accurately characterizing the course of cognitive problems in survivors of AYA cancer.

\section{Intervention research}

The one article on rehabilitation gave encouraging results for improving function in survivors of AYA cancer ${ }^{50}$. Trials of non-pharmacological and pharmacological interventions with other age groups also show promising results $5,7,8$. Survivors of AYA cancer have long life expectancies during which to contribute to society so interventions targeted to this population are critical to helping them overcome cognitive impairments.

\section{Cognitive neuroscience research}

Apple et al.' $\mathrm{s}^{26}$ imaging study showed structural differences between the brains of AYA breast cancer survivors and controls, pointing to a need for further imaging and other cognitive neuroscience research. Studies using EEG, MRI, fMRI, fNIRS, and other methods are needed to identify changes in the brains of cancer survivors before, during, and after undergoing different therapies and their relationship to function.

\section{Technology use}

The inconvenience and logistical challenges associated with research participation are particularly burdensome for underserved groups who are often underrepresented in research-those who are young, single, low-income, or unemployed ${ }^{67}$. Effective use of technology can help lower these barriers, enabling people to participate who might otherwise be unable. Mobile health technologies are especially attractive for reaching younger people since $96 \%$ of those ages 18 to 29 in the US own a smartphone, and many younger, lower-income, and non-white Americans depend on a smartphone as their only means of internet access ${ }^{68}$. Beyond the research phase, technology is also a scalable means of implementing assessments and delivery of interventions ${ }^{8,69}$. 


\section{Conclusion}

\section{Study Limitations}

Due to the aforementioned variability in definitions and measurements for $\mathrm{CRCl}$, as well as the diversity of cancer types and treatments across studies, estimates of $\mathrm{CRCl}$ prevalence in different AYA survivor populations need to be confirmed with further research. Inconsistency in terminology around cognitive impairment also may have limited our ability to comprehensively identify all publications measuring $\mathrm{CRCl}$ in AYA populations. Despite these limitations, this review provides broad guidance for future research exploring the impact and treatment of $\mathrm{CRCl}$ in AYA cancer survivors.

Lingering cancer-related cognitive impairments are common after treatment ends and can have long-term consequences for survivors, especially adolescent and young adult survivors pursuing an education or career. To advance the goal of developing age-specific guidelines for mitigating $\mathrm{CRCI}$ for AYAs this review collated the original research on cognitive symptoms, identified gaps, and specified priorities for future research. Factors positively associated with $\mathrm{CRCl}$ were older age, female gender, higher dose chemotherapy, and comorbidities. Ongoing impacts of $\mathrm{CRCl}$ are impaired role functioning and unmet needs. However, the encouraging results from the single intervention study proved the viability of a program to improve cognition and functioning in AYA cancer survivors. Additional longitudinal and intervention studies, particularly those leveraging digital health technologies, are necessary to develop evidence-based $\mathrm{CRCl}$ mitigation strategies for survivors of adolescent and young adult cancer.

\section{REFERENCES}

1. Adolescent and Young Adult Oncology Progress Review Group. Closing the Gap: Research and Care Imperatives for Adolescents and Young Adults with Cancer. Department of Health and Human Services, National Institutes of Health, National Cancer Institute, and the LiveStrong Young Adult Alliance; 2006. Report No.: NIH Publication No 06-6067.

2. American Cancer Society. Cancer Facts \& Figures 2020: Special Section: Cancer in Adolescents and Young Adults. Atlanta, GA: American Cancer Society; 2020. 
3. Docherty SL, Kayle M, Maslow GR, Santacroce SJ. The Adolescent and Young Adult with Cancer: A Developmental Life Course Perspective. Semin Oncol Nurs. 2015 Aug;31(3):186-96.

4. Beckjord EB, Reynolds KA, van Londen GJ, Burns R, Singh R, Arvey SR, et al. Population-level trends in posttreatment cancer survivors' concerns and associated receipt of care: results from the 2006 and 2010 LIVESTRONG surveys. J Psychosoc Oncol. 2014;32(2):125-51.

5. Cerulla Torrente N, Navarro Pastor J-B, de la Osa Chaparro N. Systematic review of cognitive sequelae of non-central nervous system cancer and cancer therapy. J Cancer Surviv. 2020 Aug 1;14(4):464-82.

6. Krull KR, Hardy KK, Kahalley LS, Schuitema I, Kesler SR. Neurocognitive Outcomes and Interventions in Long-Term Survivors of Childhood Cancer. JCO. 2018 Jun 6;36(21):2181-9.

7. Lv L, Mao S, Dong H, Hu P, Dong R. Pathogenesis, Assessments, and Management of ChemotherapyRelated Cognitive Impairment (CRCI): An Updated Literature Review. J Oncol [Internet]. 2020 Jun 24 [cited 2021 Jan 6];2020. Available from: https://www.ncbi.nlm.nih.gov/pmc/articles/PMC7333028/

8. Pendergrass JC, Targum SD, Harrison JE. Cognitive Impairment Associated with Cancer: A Brief Review. Innov Clin Neurosci. 2018 Feb 1;15(1-2):36-44.

9. Wefel JS, Kesler SR, Noll KR, Schagen SB. Clinical Characteristics, Pathophysiology, and Management of Noncentral Nervous System Cancer-Related Cognitive Impairment in Adults. CA Cancer J Clin. 2015 Mar;65(2):123-38.

10. Janelsins MC, Kesler SR, Ahles TA, Morrow GR. PREVALENCE, MECHANISMS, AND MANAGEMENT OF CANCER-RELATED COGNITIVE IMPAIRMENT. Int Rev Psychiatry. 2014 Feb;26(1):102-13.

11. Jean-Pierre P, McDonald BC. Neuroepidemiology of cancer and treatment-related neurocognitive dysfunction in adult-onset cancer patients and survivors. Handb Clin Neurol. 2016;138:297-309.

12. Hermelink K, Voigt V, Kaste J, Neufeld F, Wuerstlein R, Bühner M, et al. Elucidating pretreatment cognitive impairment in breast cancer patients: the impact of cancer-related post-traumatic stress. J Natl Cancer Inst. 2015 Jul;107(7).

13. van der Willik KD, Hauptmann M, Jóźwiak K, Vinke EJ, Ruiter R, Stricker BH, et al. Trajectories of Cognitive Function Prior to Cancer Diagnosis: A Population-Based Study. J Natl Cancer Inst. 2020 May 1;112(5):480-8.

14. Rodriguez N, Fawcett JM, Rash JA, Lester R, Powell E, MacMillan CD, et al. Factors associated with cognitive impairment during the first year of treatment for nonmetastatic breast cancer. Cancer Med. 2021 Feb;10(4):1191-200.

15. Costa DSJ, Fardell JE. Why Are Objective and Perceived Cognitive Function Weakly Correlated in Patients With Cancer? JCO. 2019 Mar 28;37(14):1154-8.

16. Wefel JS, Vardy J, Ahles T, Schagen SB. International Cognition and Cancer Task Force recommendations to harmonise studies of cognitive function in patients with cancer. Lancet Oncol. 2011 Jul;12(7):703-8.

17. Henneghan AM, Van Dyk K, Kaufmann T, Harrison R, Gibbons C, Heijnen C, et al. Measuring Self-Reported Cancer-Related Cognitive Impairment: Recommendations From the Cancer Neuroscience Initiative Working Group. JNCI: Journal of the National Cancer Institute [Internet]. 2021 Feb 26 [cited 2021 May 4];(djab027). Available from: https://doi.org/10.1093/jnci/djab027 
18. Schilder CM, Seynaeve C, Linn SC, Boogerd W, Gundy CM, Beex LV, et al. The impact of different definitions and reference groups on the prevalence of cognitive impairment: a study in postmenopausal breast cancer patients before the start of adjuvant systemic therapy. Psychooncology. 2010 Apr;19(4):415-22.

19. Baker KS, Syrjala KL. Long-term complications in adolescent and young adult leukemia survivors. Hematology Am Soc Hematol Educ Program. 2018 Nov 30;2018(1):146-53.

20. Gupta S. Adolescents and young adults with cancer and the risk of subsequent primary neoplasms: not just big children. The Lancet Oncology. 2019 Apr 1;20(4):466-7.

21. Lupien SJ, McEwen BS, Gunnar MR, Heim C. Effects of stress throughout the lifespan on the brain, behaviour and cognition. Nat Rev Neurosci. 2009 Jun;10(6):434-45.

22. Mañas-Ojeda A, Ros-Bernal F, Olucha-Bordonau FE, Castillo-Gómez E. Becoming Stressed: Does the Age Matter? Reviewing the Neurobiological and Socio-Affective Effects of Stress throughout the Lifespan. International Journal of Molecular Sciences. 2020;21(16):5819.

23. Salsman JM, Bingen K, Barr RD, Freyer DR. Understanding, measuring, and addressing the financial impact of cancer on adolescents and young adults. Pediatr Blood Cancer. 2019 Jul;66(7):e27660.

24. Tricco AC, Lillie E, Zarin W, O’Brien KK, Colquhoun H, Levac D, et al. PRISMA Extension for Scoping Reviews (PRISMA-ScR): Checklist and Explanation. Ann Intern Med. 2018 Oct 2;169(7):467-73.

25. Hong QN, Fàbregues S, Bartlett G, Boardman F, Cargo M, Dagenais P, et al. The Mixed Methods Appraisal Tool (MMAT) version 2018 for information professionals and researchers. Education for Information. 2018 Jan 1;34(4):285-91.

26. Apple AC, Ryals AJ, Alpert KI, Wagner LI, Shih P-A, Dokucu M, et al. Subtle hippocampal deformities in breast cancer survivors with reduced episodic memory and self-reported cognitive concerns. Neuroimage Clin. 2017;14:685-91.

27. Cheng ASK, Zeng Y, Liu X, Liu S, Cheng SWC, Kwok CTT, et al. Cognitive challenges while at work and work output in breast cancer survivors employed in a rapidly evolving economy. J Cancer Surviv. 2018;12(6):753-61.

28. Hall AE, Boyes AW, Bowman J, Walsh RA, James EL, Girgis A. Young adult cancer survivors' psychosocial well-being: a cross-sectional study assessing quality of life, unmet needs, and health behaviors. Support Care Cancer. 2012 Jun 1;20(6):1333-41.

29. Nolte S, Liegl G, Petersen MA, Aaronson NK, Costantini A, Fayers PM, et al. General population normative data for the EORTC QLQ-C30 health-related quality of life questionnaire based on 15,386 persons across 13 European countries, Canada and the Unites States. Eur J Cancer. 2019 Jan;107:153-63.

30. Huang I-C, Hudson MM, Robison LL, Krull KR. Differential Impact of Symptom Prevalence and Chronic Conditions on Quality of Life in Cancer Survivors and Non-Cancer Individuals: A Population Study. Cancer Epidemiol Biomarkers Prev. 2017;26(7):1124-32.

31. Husson O, Prins JB, Kaal SEJ, Oerlemans S, Stevens WB, Zebrack B, et al. Adolescent and young adult (AYA) lymphoma survivors report lower health-related quality of life compared to a normative population: results from the PROFILES registry. Acta Oncologica. 2017 Feb 1;56(2):288-94.

32. Husson 0, Zebrack BJ. Perceived impact of cancer among adolescents and young adults: Relationship with health-related quality of life and distress. Psychooncology. 2017 Sep;26(9):1307-15. 
33. Jones JM, Fitch M, Bongard J, Maganti M, Gupta A, D'Agostino N, et al. The Needs and Experiences of PostTreatment Adolescent and Young Adult Cancer Survivors. J Clin Med. 2020 May 13;9(5).

34. Keegan THM, Lichtensztajn DY, Kato I, Kent EE, Wu X-C, West MM, et al. Unmet adolescent and young adult cancer survivors information and service needs: a population-based cancer registry study. J Cancer Surviv. 2012 Sep;6(3):239-50.

35. Ketterl TG, Syrjala KL, Casillas J, Jacobs LA, Palmer SC, McCabe MS, et al. Lasting effects of cancer and its treatment on employment and finances in adolescent and young adult cancer survivors. Cancer. 2019 01;125(11):1908-17.

36. Kreissl S, Müller H, Goergen H, Meissner J, Topp M, Sökler M, et al. Health-Related Quality of Life in Patients With Hodgkin Lymphoma: A Longitudinal Analysis of the German Hodgkin Study Group. J Clin Oncol. 2020 Sep 1;38(25):2839-48.

37. Monteiro S, Torres A, Morgadinho R, Pereira A. Psychosocial outcomes in young adults with cancer: emotional distress, quality of life and personal growth. Arch Psychiatr Nurs. 2013 Dec;27(6):299-305.

38. Nowe E, Friedrich M, Leuteritz K, Sender A, Stöbel-Richter Y, Schulte T, et al. Cancer-Related Fatigue and Associated Factors in Young Adult Cancer Patients. J Adolesc Young Adult Oncol. 2019 Jun;8(3):297303.

39. Nugent BD, Bender CM, Sereika SM, Tersak JM, Rosenzweig M. Cognitive and Occupational Function in Survivors of Adolescent Cancer. J Adolesc Young Adult Oncol. 2018 Feb;7(1):79-87.

40. Parsons HM, Harlan LC, Lynch CF, Hamilton AS, Wu X-C, Kato I, et al. Impact of cancer on work and education among adolescent and young adult cancer survivors. J Clin Oncol. 2012 Jul 1;30(19):2393400.

41. Prasad PK, Hardy KK, Zhang N, Edelstein K, Srivastava D, Zeltzer L, et al. Psychosocial and Neurocognitive Outcomes in Adult Survivors of Adolescent and Early Young Adult Cancer: A Report From the Childhood Cancer Survivor Study. J Clin Oncol. 2015 Aug 10;33(23):2545-52.

42. Rey D, Bouhnik A-D, Mancini J, Bendiane M-K, Séror V, Viens P. Self-reported cognitive impairment after breast cancer treatment in young women from the ELIPPSE40 cohort: the long-term impact of chemotherapy. Breast J. 2012 Sep;18(5):406-14.

43. Skoogh J, Steineck G, Stierner U, Cavallin-Ståhl E, Wilderäng U, Wallin A, et al. Testicular-cancer survivors experience compromised language following chemotherapy: findings in a Swedish population-based study 3-26 years after treatment. Acta Oncol. 2012 Feb;51(2):185-97.

44. Smith AW, Bellizzi KM, Keegan THM, Zebrack B, Chen VW, Neale AV, et al. Health-related quality of life of adolescent and young adult patients with cancer in the United States: the Adolescent and Young Adult Health Outcomes and Patient Experience study. J Clin Oncol. 2013 Jun 10;31(17):2136-45.

45. Stadtbaeumer N, Müller H, Goergen H, Kreissl S, Borchmann P, Mayer A. The interplay between cancerrelated fatigue and functional health in Hodgkin lymphoma survivors. Health Psychol. 2020 Oct;39(10):905-11.

46. Szalda D, Schapira MM, Jacobs LA, Palmer SC, Vachani C, Metz J, et al. Survivorship Care Planning for Young Adults After Cancer Treatment: Understanding Care Patterns and Patient-Reported Outcomes. J Adolesc Young Adult Oncol. 2018 Aug;7(4):430-7. 
47. Trachtenberg E, Mashiach T, Ben Hayun R, Tadmor T, Fisher T, Aharon-Peretz J, et al. Cognitive impairment in hodgkin lymphoma survivors. Br J Haematol. 2018;182(5):670-8.

48. Wefel JS, Vidrine DJ, Marani SK, Swartz RJ, Veramonti TL, Meyers CA, et al. A prospective study of cognitive function in men with non-seminomatous germ cell tumors. Psychooncology. 2014 Jun;23(6):626-33.

49. Armin JS, Marshall CA, Kroeger S. Exploring the Experiences of University Students with a History of Cancer: A Pilot Study. J Cancer Educ. 2019 Nov 27;

50. Hauken MA, Larsen TMB, Holsen I. "Back on Track": A Longitudinal Mixed Methods Study on the Rehabilitation of Young Adult Cancer Survivors. Journal of Mixed Methods Research. 2017;13(3):33960 .

51. Hydeman JA, Uwazurike OC, Adeyemi EI, Beaupin LK. Survivorship needs of adolescent and young adult cancer survivors: a concept mapping analysis. J Cancer Surviv. 2019 Feb;13(1):34-42.

52. Vetsch J, Wakefield CE, McGill BC, Cohn RJ, Ellis SJ, Stefanic N, et al. Educational and vocational goal disruption in adolescent and young adult cancer survivors. Psycho-Oncol. 2018 Feb;27(2):532-8.

53. Brauer ER, Pieters HC, Ganz PA, Landier W, Pavlish C, Heilemann MV. "From Snail Mode to Rocket Ship Mode": Adolescents and Young Adults' Experiences of Returning to Work and School After Hematopoietic Cell Transplantation. J Adolesc Young Adult Oncol. 2017 Dec;6(4):551-9.

54. D'Agostino NM, Edelstein K. Psychosocial challenges and resource needs of young adult cancer survivors: implications for program development. J Psychosoc Oncol. 2013;31(6):585-600.

55. Elsbernd A, Pedersen KJ, Boisen KA, Midtgaard J, Larsen HB. "On Your Own”: Adolescent and Young Adult Cancer Survivors' Experience of Managing Return to Secondary or Higher Education in Denmark. J Adolesc Young Adult Oncol. 2018;7(5):618-25.

56. Fauske L, Bondevik H, Ahlberg K, Bjørndal A. Identifying bone sarcoma survivors facing psychosocial challenges. A study of trajectories following treatment. Eur J Cancer Care (Engl). 2019 Sep;28(5):e13119.

57. Hauken MA, Grue M, Dyregrov A. "It's been a life-changing experience!” A qualitative study of young adult cancer survivors' experiences of the coexistence of negative and positive outcomes after cancer treatment. Scandinavian Journal of Psychology. 2019;60(6):577-84.

58. Lopez A-LJ, Butow PN, Philp S, Hobbs K, Phillips E, Robertson R, et al. Age-related supportive care needs of women with gynaecological cancer: A qualitative exploration. Eur J Cancer Care (Engl). 2019 Jul;28(4):e13070.

59. McLoone JK, Wakefield CE, Butow P, Fleming C, Cohn RJ. Returning to School After Adolescent Cancer: A Qualitative Examination of Australian Survivors' and Their Families' Perspectives. J Adolesc Young Adult Oncol. 2011 Jun;1(2):87-94.

60. Ruddy KJ, Greaney ML, Sprunck-Harrild K, Meyer ME, Emmons KM, Partridge AH. Young Women with Breast Cancer: A Focus Group Study of Unmet Needs. J Adolesc Young Adult Oncol. 2013 Dec 1;2(4):153-60.

61. Stevens MCG, Beynon P, Cameron A, Cargill J, Cheshire J, Dolby S. Understanding and Utilizing the Unmet Needs of Teenagers and Young Adults with Cancer to Determine Priorities for Service Development: 
The Macmillan On Target Programme. Journal of Adolescent and Young Adult Oncology. 2018 Jul 10;7(6):652-9.

62. Lang MJ, Giese-Davis J, Patton SB, Campbell DJT. Does age matter? Comparing post-treatment psychosocial outcomes in young adult and older adult cancer survivors with their cancer-free peers. Psychooncology. 2018 May;27(5):1404-11.

63. Hauken MA, Larsen TMB, Holsen I. Meeting reality: young adult cancer survivors' experiences of reentering everyday life after cancer treatment. Cancer Nurs. 2013 Oct;36(5):E17-26.

64. Andreotti C, Root JC, Schagen SB, McDonald BC, Saykin AJ, Atkinson TM, et al. Reliable change in neuropsychological assessment of breast cancer survivors. Psychooncology. 2016 Jan;25(1):43-50.

65. Bower JE, Crosswell AD, Slavich GM. Childhood Adversity and Cumulative Life Stress: Risk Factors for Cancer-Related Fatigue. Clin Psychol Sci. 2014 Jan;2(1):108-15.

66. Halfon N, Larson K, Lu M, Tullis E, Russ S. Lifecourse health development: past, present and future. Matern Child Health J. 2014 Feb;18(2):344-65.

67. Wiegner L, Hange D, Björkelund C, Ahlborg G. Prevalence of perceived stress and associations to symptoms of exhaustion, depression and anxiety in a working age population seeking primary care - an observational study. BMC Fam Pract [Internet]. 2015 Mar 19 [cited 2020 Sep 25];16. Available from: https://www.ncbi.nlm.nih.gov/pmc/articles/PMC4377029/

68. Pew Research Center. Demographics of Mobile Device Ownership and Adoption in the United States [Internet]. [cited 2020 Aug 13]. Available from: https://www.pewresearch.org/internet/factsheet/mobile/

69. Von Ah D, Crouch A. Cognitive Rehabilitation for Cognitive Dysfunction after Cancer and Cancer Treatment: Implications for Nursing Practice. Semin Oncol Nurs. 2020 Feb;36(1):150977. 


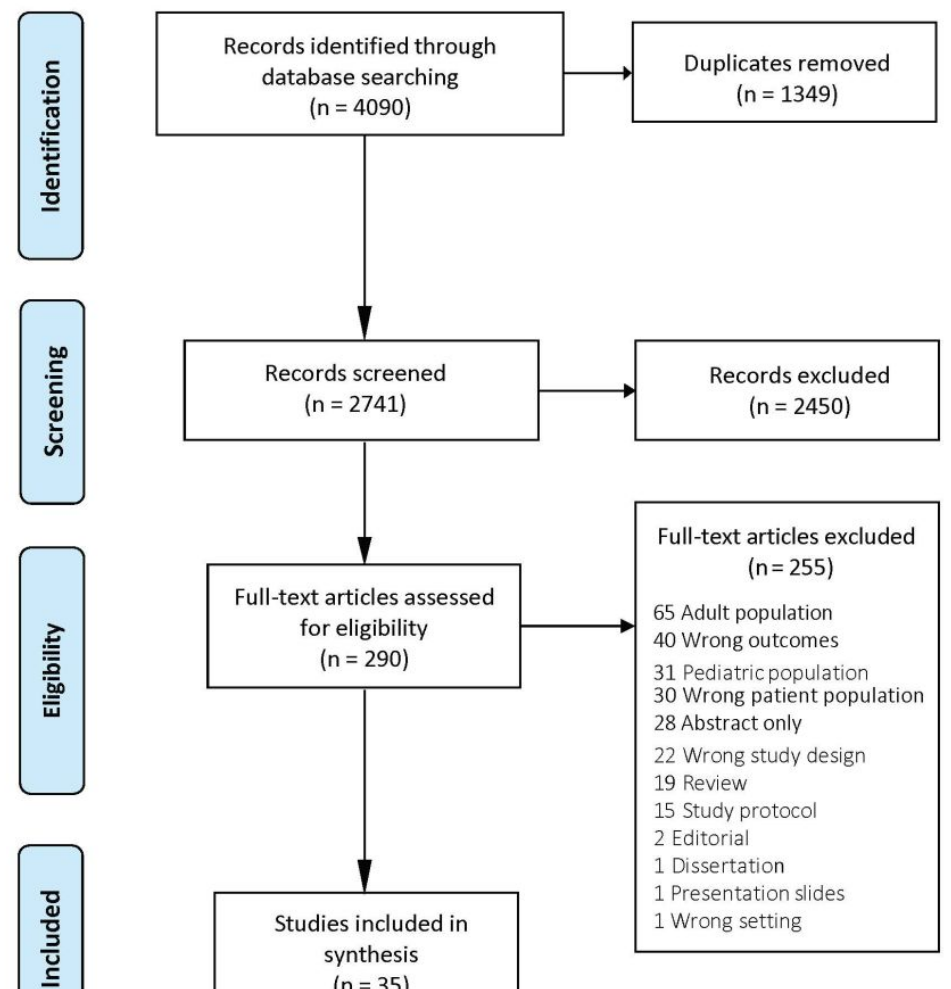




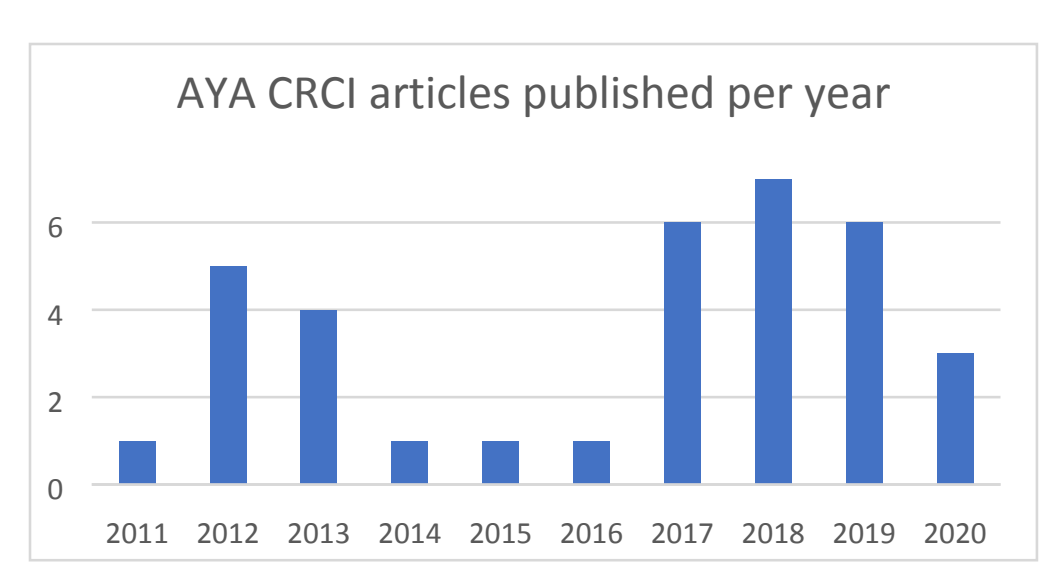

8




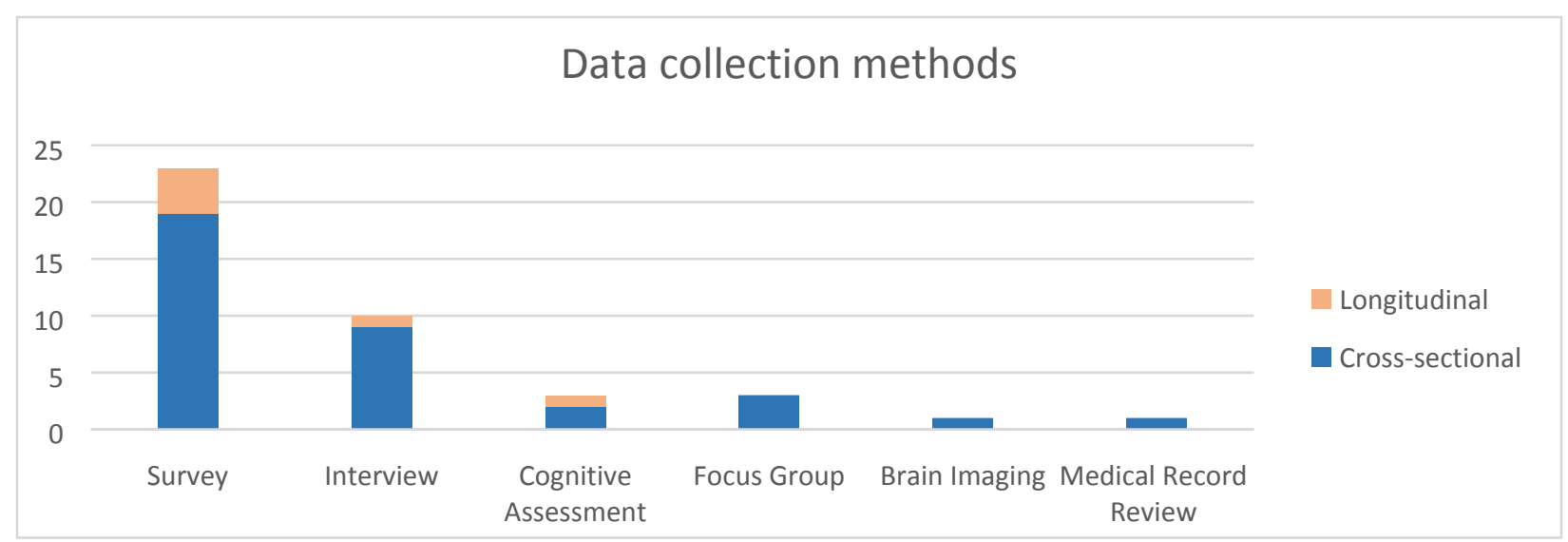

(1)

(n)

6

8




\begin{tabular}{|c|c|c|c|c|c|}
\hline Article & Method & Participants & Measures & Cognitive Results / Outcomes & $\begin{array}{l}\text { MMAT limitations } \\
\text { (score) }\end{array}$ \\
\hline \multicolumn{6}{|l|}{ Quantitative } \\
\hline $\begin{array}{l}\text { Apple } \\
(2017)^{26}\end{array}$ & $\begin{array}{l}\text { Cross- } \\
\text { sectional } \\
\text { imaging } \\
\text { study }\end{array}$ & $\begin{array}{l}\text { Age } 18-45 \text { : } \\
\text { - } 16 \text { pre-menopausal } \\
\text { breast cancer } \\
\text { survivors } \\
\text { - } 18 \text { controls }\end{array}$ & \begin{tabular}{|l|} 
Hippocampal \\
deformation, \\
Neuro-QOL \\
Cognitive \\
Function, NIH \\
Toolbox \\
Cognition Battery
\end{tabular} & $\begin{array}{l}\text { - Compared to controls, survivors show more inward } \\
\text { hippocampal deformation, worse cognitive } \\
\text { functioning, and lower episodic memory test scores. } \\
\text { - Compared to controls, survivors reported significantly } \\
\text { more general cognitive concerns. }\end{array}$ & $\begin{array}{l}\text { Limited sample, } \\
\text { risk of biased } \\
\text { sample }(40 \%)\end{array}$ \\
\hline $\begin{array}{l}\text { Cheng } \\
(2018)^{27}\end{array}$ & $\begin{array}{l}\text { Cross- } \\
\text { sectional } \\
\text { survey }\end{array}$ & $\begin{array}{l}\text { Ages } 20-60 \text { at survey, } \\
>2 \text { years post- } \\
\text { treatment: } \\
\text { - } 267 \text { breast cancer } \\
\text { survivors } \\
\text { - } 267 \text { controls }\end{array}$ & $\begin{array}{l}\text { BRFSS job } \\
\text { stress, HADS, } \\
\text { EORTC QLQ- } \\
\text { C30, CSC-21, } \\
\text { WLQ output scale }\end{array}$ & $\begin{array}{l}\text { - After correcting for age, depression, anxiety, and } \\
\text { fatigue, having more cognitive symptoms is related to } \\
\text { lower quantity, quality, and timeliness of work for } \\
\text { survivors but not controls. }\end{array}$ & $\begin{array}{l}\text { Risk of biased } \\
\text { sample and non- } \\
\text { response bias } \\
(60 \%)\end{array}$ \\
\hline Hall (2012) ${ }^{28}$ & $\begin{array}{l}\text { Cross- } \\
\text { sectional } \\
\text { survey } \\
\text { (Cancer } \\
\text { Survival } \\
\text { Study) }\end{array}$ & $\begin{array}{l}\text { - } 58 \text { survivors age 18- } \\
40 \text { at diagnosis } \\
\text { - } 58 \text { gender and } \\
\text { cancer-type matched } \\
\text { older adults }\end{array}$ & $\begin{array}{l}\text { SCNS-SF34, } \\
\text { EORTC QLQ- } \\
\text { C30, items on } \\
\text { smoking, alcohol } \\
\text { consumption, and } \\
\text { physical activity }\end{array}$ & $\begin{array}{l}\text { - No significant difference between younger and older } \\
\text { survivors on cognitive functioning. } \\
\text { - No comparison to normative data is given in the } \\
\text { article but the mean score is not significantly lower } \\
\text { than published normative data adjusted for age }{ }^{29} \text {. }\end{array}$ & $\begin{array}{l}\text { None } \\
(100 \%)\end{array}$ \\
\hline $\begin{array}{l}\text { Huang } \\
(2017)^{30}\end{array}$ & $\begin{array}{l}\text { Cross- } \\
\text { sectional } \\
\text { interview }\end{array}$ & $\begin{array}{l}604 \text { survivors, } 6166 \\
\text { controls: }\end{array}$ & $\begin{array}{l}\text { NHIS symptom } \\
\text { and cognitive } \\
\text { disturbance }\end{array}$ & $\begin{array}{l}\text { - Overall, survivors experienced more cognitive issues } \\
\text { than controls ( } 32 \% \text { vs. } 21 \%) \text {, but younger survivors }\end{array}$ & $\begin{array}{l}\text { None } \\
(100 \%)\end{array}$ \\
\hline
\end{tabular}




\begin{tabular}{|c|c|c|c|c|c|}
\hline Article & Method & Participants & Measures & Cognitive Results / Outcomes & $\begin{array}{c}\text { MMAT limitations } \\
\text { (score) }\end{array}$ \\
\hline & $\begin{array}{l}\text { (National } \\
\text { Health } \\
\text { Interview } \\
\text { Study) }\end{array}$ & $\begin{array}{l}\text { - Age 18-44: } 53 \\
\text { survivors, } 3082 \\
\text { controls } \\
\text { - Age 45-64: } 229 \\
\text { survivors, } 2028 \\
\text { controls } \\
\text { - Age >64: } 322 \\
\text { survivors, } 1056 \\
\text { controls }\end{array}$ & $\begin{array}{l}\text { questions, Global } \\
\text { Health Scale } \\
\text { (PROMIS) }\end{array}$ & $\begin{array}{l}\text { had significantly less CRCI. Prevalence was not } \\
\text { reported by age. } \\
\text { - Cognitive disturbance was associated with } \\
\text { significantly lower mental and physical quality of life } \\
\text { for all ages. }\end{array}$ & \\
\hline $\begin{array}{l}\text { Husson } \\
(2017)^{31}\end{array}$ & $\begin{array}{l}\text { Cross- } \\
\text { sectional } \\
\text { survey }\end{array}$ & $\begin{array}{l}\text { - } 198 \text { lymphoma } \\
\text { survivors age 18-39 } \\
\text { at diagnosis } \\
\text { - } 380 \text { age-and sex- } \\
\text { matched controls }\end{array}$ & $\begin{array}{l}\text { EORTC QLQ- } \\
\text { C30, HADS }\end{array}$ & $\begin{array}{l}\text { - Compared to controls, survivors scored significantly } \\
\text { worse on cognitive HRQoL domains } \\
\text { - Low HRQoL associated with being female, } \\
\text { unemployed, having comorbid conditions, fatigue, } \\
\text { anxiety, depression }\end{array}$ & $\begin{array}{l}\text { None } \\
(100 \%)\end{array}$ \\
\hline $\begin{array}{l}\text { Husson } \\
(2017)^{32}\end{array}$ & $\begin{array}{l}\text { Cross- } \\
\text { sectional } \\
\text { survey }\end{array}$ & $\begin{array}{l}173 \text { survivors age } 15-29 \\
\text { at diagnosis and 18-39 } \\
\text { at study }\end{array}$ & $\begin{array}{l}\text { IOC-AYA version, } \\
\text { SF-36, BSI-18 }\end{array}$ & $\begin{array}{l}\text { - Lower cognitive function associated with being } \\
\text { female, being unemployed, and having had leukemia, } \\
\text { current health problems, distress, or a cancer with } \\
\text { lower survival rate }\end{array}$ & $\begin{array}{l}\text { Risk of biased } \\
\text { sample and non- } \\
\text { response bias } \\
(60 \%)\end{array}$ \\
\hline $\begin{array}{l}\text { Jones } \\
(2020)^{33}\end{array}$ & $\begin{array}{l}\text { Cross- } \\
\text { sectional } \\
\text { survey } \\
\text { (Transitions } \\
\text { Study) }\end{array}$ & $\begin{array}{l}575 \text { survivors ages } 18- \\
34 \text { within } 5 \text { years of } \\
\text { completing treatment }\end{array}$ & $\begin{array}{l}\text { Surveys to } \\
\text { identify unmet } \\
\text { needs and } \\
\text { associated risk } \\
\text { factors }\end{array}$ & $\begin{array}{l}\text { - } 49 \% \text { reported changes to concentration and/or } \\
\text { memory. } \\
\text { - } 41 \% \text { sought help for cognitive changes and } 47 \% \text { of } \\
\text { those had difficulty obtaining help. }\end{array}$ & $\begin{array}{l}\text { Risk of biased } \\
\text { sample and non- } \\
\text { response bias } \\
(60 \%)\end{array}$ \\
\hline
\end{tabular}




\begin{tabular}{|c|c|c|c|c|c|}
\hline Article & Method & Participants & Measures & Cognitive Results / Outcomes & $\begin{array}{c}\text { MMAT limitations } \\
\text { (score) }\end{array}$ \\
\hline $\begin{array}{l}\text { Keegan } \\
(2012)^{34}\end{array}$ & $\begin{array}{l}\text { Cross- } \\
\text { sectional } \\
\text { survey } \\
\text { (AYA- } \\
\text { HOPE } \\
\text { survey) }\end{array}$ & $\begin{array}{l}523 \text { survivors age } 15-39 \\
\text { at diagnosis }\end{array}$ & $\begin{array}{l}\text { Self-reported } \\
\text { needs and } \\
\text { outcomes, chart } \\
\text { abstraction }\end{array}$ & $\begin{array}{l}\text { - Survivors are more likely than patients to have an } \\
\text { unmet need. } \\
\text { - Having more than three symptoms (including } \\
\text { problems with memory, concentration, or attention) } \\
\text { was associated with having unmet needs. }\end{array}$ & $\begin{array}{l}\text { Risk of biased } \\
\text { sample and non- } \\
\text { response bias } \\
(60 \%)\end{array}$ \\
\hline $\begin{array}{l}\text { Ketterl } \\
(\mathbf{2 0 1 9})^{35}\end{array}$ & $\begin{array}{l}\text { Cross- } \\
\text { sectional } \\
\text { survey }\end{array}$ & $\begin{array}{l}872 \text { survivors age } 18-39 \\
\text { at diagnosis, }>1 \mathrm{yr} \text { since } \\
\text { treatment and } 1-5 \mathrm{yr} \\
\text { since diagnosis }\end{array}$ & $\begin{array}{l}\text { Online survey } \\
\text { related to } \\
\text { physical and } \\
\text { mental } \\
\text { impairment, work, } \\
\text { and finances; } \\
\text { medical chart } \\
\text { abstraction }\end{array}$ & $\begin{array}{l}\text { - } 54.2 \% \text { reported interference with mental tasks at } \\
\text { work or in studies } \\
\text { - Higher mental impairment at work for breast cancer } \\
\text { survivors was associated with radiation or } \\
\text { chemotherapy. } \\
\text { - Higher mental impairment at work in 'other' cancer } \\
\text { survivors was associated with chemotherapy or } \\
\text { surgery. }\end{array}$ & $\begin{array}{l}\text { Risk of biased } \\
\text { sample and non- } \\
\text { response bias } \\
(60 \%)\end{array}$ \\
\hline $\begin{array}{l}\text { Kreissl } \\
(\mathbf{2 0 2 0})^{36}\end{array}$ & $\begin{array}{l}\text { Longitudinal } \\
\text { survey }\end{array}$ & $\begin{array}{l}4215 \text { Hodgkin } \\
\text { lymphoma survivors } \\
\text { age } 18-60 \text { (mean=35.1, } \\
S D=11.4 \text { ) from prior to } \\
\text { diagnosis through } 5 \\
\text { years after treatment }\end{array}$ & $\begin{array}{l}\text { EORTC QLQ- } \\
\text { C30 }\end{array}$ & $\begin{array}{l}\text { - Cognitive deficit was noted prior to treatment and } \\
\text { worsened during treatment. } \\
\text { - Cognition improved somewhat after treatment but } \\
\text { was still severely and persistently affected during } \\
\text { survivorship. } \\
\text { - Being older and/or female associated with lower } \\
\text { cognition. } \\
\text { - Level of cognitive deficit not influenced by treatment } \\
\text { type. }\end{array}$ & $\begin{array}{l}\text { Small risk of bias } \\
(80 \%)\end{array}$ \\
\hline
\end{tabular}




\begin{tabular}{|c|c|c|c|c|c|}
\hline Article & Method & Participants & Measures & Cognitive Results / Outcomes & $\begin{array}{l}\text { MMAT limitations } \\
\text { (score) }\end{array}$ \\
\hline & & & & $\begin{array}{l}\text { - Reported correlation with psychosocial symptoms, } \\
\text { health factors, and worse finances. }\end{array}$ & \\
\hline $\begin{array}{l}\text { Monteiro } \\
(2013)^{37}\end{array}$ & $\begin{array}{l}\text { Cross- } \\
\text { sectional } \\
\text { survey }\end{array}$ & $\begin{array}{l}\text { Age } 20-39 \text { : } \\
\text { - } 11 \text { patients age } 20-39 \\
\text { at diagnosis } \\
\text { - } 25 \text { survivors age } 15- \\
39 \text { at diagnosis } \\
\text { - } 435 \text { controls }\end{array}$ & $\begin{array}{l}\text { EORTC QLQ- } \\
\text { C30, personal } \\
\text { growth subscale } \\
\text { of PWBS }\end{array}$ & $\begin{array}{l}\text { - Patients scored significantly lower on cognitive } \\
\text { function than controls. } \\
\text { - Survivors' scores were between those of patients and } \\
\text { controls but did not differ significantly from either. }\end{array}$ & $\begin{array}{l}\text { Limited sample, } \\
\text { risk of biased } \\
\text { sample and non- } \\
\text { response bias } \\
(40 \%)\end{array}$ \\
\hline $\begin{array}{l}\text { Nowe } \\
(2019)^{38}\end{array}$ & $\begin{array}{l}\text { Cross- } \\
\text { sectional } \\
\text { survey }\end{array}$ & $\begin{array}{l}577 \text { survivors age } 18-39 \\
\text { at diagnosis }\end{array}$ & $\begin{array}{l}\text { EORTC QLQ- } \\
\text { FA12 }\end{array}$ & $\begin{array}{l}\text { - Higher cognitive fatigue was associated with being } \\
\text { female, having financial problems, and having } \\
\text { additional diseases. } \\
\text { - Breast and gynecological cancer survivors had the } \\
\text { highest cognitive fatigue scores and testicular cancer } \\
\text { survivors had the lowest. }\end{array}$ & $\begin{array}{l}\text { None } \\
(100 \%)\end{array}$ \\
\hline $\begin{array}{l}\text { Nugent } \\
(2018)^{39}\end{array}$ & $\begin{array}{l}\text { Cross- } \\
\text { sectional } \\
\text { surveys and } \\
\text { cognitive } \\
\text { assessment } \\
\text { s }\end{array}$ & $\begin{array}{l}\text { - } 23 \text { survivors age } 15- \\
21 \text { at diagnosis } \\
\text { - } 14 \text { age- and gender- } \\
\text { matched controls }\end{array}$ & $\begin{array}{l}\text { Cognitive } \\
\text { assessments: } \\
\text { DVT, DSST, } \\
\text { grooved peg } \\
\text { board, Stroop, } \\
\text { verbal fluency, } \\
\text { trail-making A } \\
\text { and B, } \\
\text { Wechsler }\end{array}$ & $\begin{array}{l}\text { - Survivors and controls showed no significant } \\
\text { difference on the neuropsychological assessments } \\
\text { - Small and medium effect sizes and direction of } \\
\text { differences in Digit Vigilance, Stroop, work output, } \\
\text { and perceived and total cognitive function suggest } \\
\text { that survivors have somewhat greater difficulty than } \\
\text { controls. } \\
\text { - Survivors reported significantly higher rate of } \\
\text { perceived memory problems. }\end{array}$ & $\begin{array}{l}\text { Risk of biased } \\
\text { sample and non- } \\
\text { response bias } \\
(60 \%)\end{array}$ \\
\hline
\end{tabular}




\begin{tabular}{|c|c|c|c|c|c|}
\hline Article & Method & Participants & Measures & Cognitive Results / Outcomes & $\begin{array}{c}\text { MMAT limitations } \\
\text { (score) }\end{array}$ \\
\hline & & & $\begin{array}{l}\text { memory scale, } \\
\text { letter number } \\
\text { sequencing, } \\
\text { Rey-Osterrieth } \\
\text { figure, WCST } \\
\text { PAOFI; CESD-R; } \\
\text { WLQ }\end{array}$ & $\begin{array}{l}\text { - Significant correlation between perceived cognitive } \\
\text { function and symptoms of depression, anxiety, and } \\
\text { fatigue. }\end{array}$ & \\
\hline $\begin{array}{l}\text { Parsons } \\
(2012)^{40}\end{array}$ & $\begin{array}{l}\text { Longitudinal } \\
\text { survey (US } \\
\text { AYA HOPE } \\
\text { survey) }\end{array}$ & $\begin{array}{l}\text { US AYA HOPE } \\
\text { participants age 15-39 } \\
\text { at diagnosis: } \\
\text { survey at } 6-14 \text { months } \\
\text { post-diagnosis } \\
(\mathrm{n}=524) \\
\text { survey at } 15-35 \\
\text { months ( } \mathrm{n}=465 \text { ) post- } \\
\text { diagnosis }\end{array}$ & PedsQL & $\begin{array}{l}\text { - Over } 50 \% \text { reported problems at work or school at } \\
\text { both } 6-14 \text { months and } 15-35 \text { months } \\
\text { - } 35 \% \text { believe treatment had a negative impact on } \\
\text { career plans } \\
\text { - Of that } 35 \%, 45 \% \text { quit work or school completely } \\
\text { Of participants working or in school full-time before } \\
\text { diagnosis, at } 15-34 \text { months: } \\
\text { - Over } 30 \% \text { reported problems with "paying attention" } \\
\text { at work/school } \\
\text { - } 53 \% \text { reported problems with "forgetting" } \\
\text { - } 28 \% \text { reported trouble "keeping up with work or } \\
\text { studies." }\end{array}$ & $\begin{array}{l}\text { Risk of biased } \\
\text { sample and non- } \\
\text { response bias } \\
(60 \%)\end{array}$ \\
\hline $\begin{array}{l}\text { Prasad } \\
(2015)^{41}\end{array}$ & $\begin{array}{l}\text { Cross- } \\
\text { sectional } \\
\text { survey }\end{array}$ & $\begin{array}{l}\text { Survivors and siblings: } \\
\text { - } 1054 \text { age } 15-21 \text { at } \\
\text { diagnosis with }\end{array}$ & $\begin{array}{l}\text { BSI-18, CCSS- } \\
\text { NCQ }\end{array}$ & $\begin{array}{l}\text { - Compared to siblings, survivors reported significantly } \\
\text { worse task efficiency, emotion regulation, and } \\
\text { memory, although survivors of lymphoma and } \\
\text { sarcoma were at lower risk than other survivors. }\end{array}$ & None $(100 \%)$ \\
\hline
\end{tabular}




\begin{tabular}{|c|c|c|c|c|c|}
\hline Article & Method & Participants & Measures & Cognitive Results / Outcomes & $\begin{array}{c}\text { MMAT limitations } \\
\text { (score) }\end{array}$ \\
\hline & & $\begin{array}{l}\text { lymphomas or } \\
\text { sarcomas } \\
\text { - } 390 \text { siblings }\end{array}$ & & $\begin{array}{l}\text { - } 21.6 \% \text { of survivors had impaired memory }(\mathrm{OR}=1.44 \\
\text { vs. siblings) } \\
\text { - } 13.9 \% \text { of survivors had impaired task efficiency } \\
\text { (OR=1.72 vs. siblings) } \\
\text { - Unemployment and inability to live independently } \\
\text { were associated with reports of impaired task } \\
\text { efficiency. }\end{array}$ & \\
\hline Rey $(2012)^{42}$ & $\begin{array}{l}\text { Cross- } \\
\text { sectional } \\
\text { survey and } \\
\text { medical } \\
\text { record } \\
\text { review }\end{array}$ & $\begin{array}{l}222 \text { breast cancer } \\
\text { survivors in French } \\
\text { ELLIPSE40 cohort, age } \\
18-40 \text { at diagnosis }\end{array}$ & $\begin{array}{l}\text { Self-reported } \\
\text { cognitive } \\
\text { impairment, CES- } \\
\text { D, WHOQOL- } \\
\text { BREF }\end{array}$ & $\begin{array}{l}-21.2 \% \text { of participants reported cognitive difficulties in } \\
\text { the six months prior to diagnosis. } \\
-37.4 \% \text { of participants reported } \mathrm{CRCl} \text { at } 10 \text { months, } \\
36.5 \% \text { at } 16 \text { months, } 42.3 \% \text { at } 28 \text { months. } \\
\text { - } 58.1 \% \text { of women reported } \mathrm{CRCl} \text { during at least one } \\
\text { interview. } \\
\text { - } \mathrm{CRCl} \text { was associated with depression, lower quality } \\
\text { of life, and social vulnerabilities. }\end{array}$ & None $(100 \%)$ \\
\hline $\begin{array}{l}\text { Skoogh } \\
(2012)^{43}\end{array}$ & $\begin{array}{l}\text { Cross- } \\
\text { sectional } \\
\text { survey }\end{array}$ & $\begin{array}{l}960 \text { men diagnosed } \\
\text { with testicular cancer. } \\
\text { Age range } 16-64 \text { at } \\
\text { diagnosis, mean=30, } \\
\text { IQR=24-35 }\end{array}$ & $\begin{array}{l}\text { Questionnaire } \\
\text { about daily } \\
\text { behavior related } \\
\text { to cognitive } \\
\text { function domains: } \\
\text { memory, } \\
\text { attention, visuo- } \\
\text { spatial, language, }\end{array}$ & $\begin{array}{l}\text { - More cognitive difficulties were associated with } 5 \text { or } \\
\text { more cycles of chemotherapy, particularly in } \\
\text { language, memory, concentration, and speed. }\end{array}$ & None $(100 \%)$ \\
\hline
\end{tabular}




\begin{tabular}{|c|c|c|c|c|c|}
\hline Article & Method & Participants & Measures & Cognitive Results / Outcomes & $\begin{array}{c}\text { MMAT limitations } \\
\text { (score) }\end{array}$ \\
\hline & & & $\begin{array}{l}\text { speed, and } \\
\text { executive }\end{array}$ & & \\
\hline $\begin{array}{l}\text { Smith } \\
(2013)^{44}\end{array}$ & $\begin{array}{l}\text { Cross- } \\
\text { sectional } \\
\text { survey } \\
\text { (AYA- } \\
\text { HOPE } \\
\text { survey) }\end{array}$ & $\begin{array}{l}523 \text { survivors age } 15- \\
39 \text { at diagnosis } \\
1171 \text { controls age } 18- \\
25\end{array}$ & PedsQL, SF-12 & $\begin{array}{l}\text { - Survivors age 15-17 reported worse work or school } \\
\text { functioning than older survivors. } \\
\text { - Higher numbers of symptoms are associated with } \\
\text { significantly worse work/school functioning }\end{array}$ & $\begin{array}{l}\text { Risk of biased } \\
\text { sample and non- } \\
\text { response bias } \\
(60 \%)\end{array}$ \\
\hline $\begin{array}{l}\text { Stadtbaeume } \\
\text { r (2020) })^{45}\end{array}$ & $\begin{array}{l}\text { Longitudinal } \\
\text { survey }\end{array}$ & $\begin{array}{l}3596 \text { Hodgkin } \\
\text { lymphoma survivors } \\
\text { age } 18-60 \text { (mean=35.3, } \\
\text { SD=11.4) from prior to } \\
\text { diagnosis through } 5 \\
\text { years after treatment }\end{array}$ & $\begin{array}{l}\text { EORTC QLQ- } \\
\text { C30 }\end{array}$ & $\begin{array}{l}\text { - Time-specific within-person improvements in } \\
\text { cognition reduced fatigue more than vice versa. } \\
\text { - Between-person association of lower cognitive } \\
\text { functioning with higher fatigue. } \\
\text { - Between-person association of higher age with lower } \\
\text { cognitive functioning. }\end{array}$ & $\begin{array}{l}\text { Small risk of bias } \\
(80 \%)\end{array}$ \\
\hline $\begin{array}{l}\text { Szalda } \\
(2018)^{46}\end{array}$ & $\begin{array}{l}\text { Cross- } \\
\text { sectional } \\
\text { survey }\end{array}$ & $\begin{array}{l}\text { Survivors: } \\
\text { - } 611 \text { age } 18-39 \text { at } \\
\text { diagnosis } \\
\text { - } 1742 \text { age } 40-60 \text { at } \\
\text { diagnosis }\end{array}$ & $\begin{array}{l}\text { Survey assessing } \\
\text { satisfaction with } \\
\text { and } \\
\text { communication of } \\
\text { survivorship care } \\
\text { plan, and patient- } \\
\text { reported late } \\
\text { effects }\end{array}$ & $\begin{array}{l}\text { - Over half }(56 \%) \text { of young survivors reported concerns } \\
\text { about neurocognitive performance, although at a } \\
\text { lower rate than older survivors. }\end{array}$ & $\begin{array}{l}\text { Limited sample, } \\
\text { risk of biased } \\
\text { sample and non- } \\
\text { response bias } \\
(40 \%)\end{array}$ \\
\hline
\end{tabular}




\begin{tabular}{|c|c|c|c|c|c|}
\hline Article & Method & Participants & Measures & Cognitive Results / Outcomes & $\begin{array}{c}\text { MMAT limitations } \\
\text { (score) }\end{array}$ \\
\hline $\begin{array}{l}\text { Trachtenberg } \\
(2018)^{47}\end{array}$ & \begin{tabular}{|l} 
Cross- \\
sectional \\
survey and \\
cognitive \\
assessment
\end{tabular} & $\begin{array}{l}51 \text { Hodgkin lymphoma } \\
\text { survivors age } 19-48 \text { at } \\
\text { study, median=28 }\end{array}$ & \begin{tabular}{|l} 
FACT-Cog, MFI- \\
20, EORTC QLQ- \\
C30, Cognitive \\
assessments: \\
BDI-II, CVLT, \\
WAIS-III-R, \\
TMT A+B, \\
Stroop, Raven \\
matrices, \\
selected \\
CANTAB (PAL, \\
SOC, IED, RTI, \\
RVP)
\end{tabular} & $\begin{array}{l}\text { - Survivors scored significantly lower than healthy } \\
\text { controls on multiple measures of cognition, primarily } \\
\text { in executive function and memory. } \\
\text { - Survivors who had fewer chemotherapy cycles had } \\
\text { better cognitive performance. } \\
\text { - Fatigue not associated with cognitive performance. } \\
\text { - FACT-Cog results were significantly correlated with } \\
\text { objective cognitive performance. }\end{array}$ & $\begin{array}{l}\text { None } \\
(100 \%)\end{array}$ \\
\hline $\begin{array}{l}\text { Wefel } \\
(2014)^{48}\end{array}$ & $\begin{array}{l}\text { Longitudinal } \\
\text { cognitive } \\
\text { assessment }\end{array}$ & $\begin{array}{l}53 \text { men with NSGCT } \\
\text { before and } 12 \mathrm{mo} \text { after } \\
\text { treatment } \\
\text { (Age mean=31.0, } \\
\text { SD=7.5, range=18.5- } \\
50.7 \text { ): } \\
\text { - } 11 \text { no chemo } \\
\text { - } 23 \text { low chemo } \\
\text { - } 28 \text { high chemo }\end{array}$ & $\begin{array}{l}\text { Digit Symbol, } \\
\text { Digit Span, } \\
\text { TMTA, HVLT, } \\
\text { TMTB, COWA, } \\
\text { GPD, GPND, } \\
\text { CES-D, STAIS }\end{array}$ & $\begin{array}{l}\text { - Men receiving chemotherapy had higher rates of } \\
\text { cognitive decline at } 12 \text { months in a dose-response } \\
\text { pattern ( } 0 \%, 52 \%, 67 \% \text { for no, low, and high groups } \\
\text { respectively). } \\
\text { - Most common was reduction in motor dexterity but } \\
\text { declines in learning and memory were also common. } \\
\text { - Younger age was associated with greater decline. }\end{array}$ & $\begin{array}{l}\text { Risk of biased } \\
\text { sample } \\
(80 \%)\end{array}$ \\
\hline
\end{tabular}




\begin{tabular}{|c|c|c|c|c|c|}
\hline Article & Method & Participants & Measures & Cognitive Results / Outcomes & $\begin{array}{c}\text { MMAT limitations } \\
\text { (score) }\end{array}$ \\
\hline $\begin{array}{l}\text { Armin } \\
(2019)^{49}\end{array}$ & $\begin{array}{l}\text { Cross- } \\
\text { sectional } \\
\text { survey }\end{array}$ & $\begin{array}{l}\text { - } 3 \text { Survivors age }<15 \text { at } \\
\text { diagnosis } \\
12 \text { survivors age } 18- \\
39 \text { at diagnosis } \\
4 \text { survivors age }>39 \text { at } \\
\text { diagnosis }\end{array}$ & $\begin{array}{l}\text { Late effects from } \\
\text { cancer or its } \\
\text { treatment }\end{array}$ & $\begin{array}{l}\text { - Cognitive changes were the most commonly reported } \\
\text { impairment } \\
\text { - } 47 \% \text { reported cognitive changes }\end{array}$ & $\begin{array}{l}\text { Little discussion } \\
\text { of qualitative } \\
\text { method, limited } \\
\text { sample, risk of } \\
\text { biased sample } \\
\text { and non- } \\
\text { response bias } \\
(53 \%)\end{array}$ \\
\hline $\begin{array}{l}\text { Hauken } \\
(2017)^{50}\end{array}$ & $\begin{array}{l}\text { Longitudinal } \\
\text { rehabilitatio } \\
n \\
\text { intervention } \\
\text { with } \\
\text { interviews } \\
\text { and surveys }\end{array}$ & $\begin{array}{l}20 \text { survivors ages } 18-35 \\
\text { diagnosed within prior } 5 \\
\text { years }\end{array}$ & $\begin{array}{l}\text { Interviews on } \\
\text { treatment and } \\
\text { rehabilitation; } \\
\text { surveys: COPM, } \\
\text { EORTC QLQ- } \\
\text { C30; physical } \\
\text { capacity } \\
\text { measures }\end{array}$ & $\begin{array}{l}\text { - Participants showed significant improvement in } \\
\text { cognitive function from baseline through the } \\
\text { rehabilitation program but did not reach the level of } \\
\text { cognitive function of normative group. } \\
\text { - Improvement was sustained into the follow-up period. }\end{array}$ & $\begin{array}{l}\text { Limited sample, } \\
\text { risk of biased } \\
\text { sample and non- } \\
\text { response bias } \\
(80 \%)\end{array}$ \\
\hline $\begin{array}{l}\text { Hydeman } \\
(2016)^{51}\end{array}$ & $\begin{array}{l}\text { Cross- } \\
\text { sectional } \\
\text { focus group }\end{array}$ & $\begin{array}{l}27 \text { survivors age } 18-39 \\
\text { at diagnosis and }>2 \mathrm{yr} \\
\text { post-treatment }\end{array}$ & $\begin{array}{l}\text { Concept mapping } \\
\text { of issues } \\
\text { important to } \\
\text { transition to } \\
\text { survivorship }\end{array}$ & $\begin{array}{l}\text { - Cognitive effects of treatment were identified as an } \\
\text { area least addressed in the transition to survivorship } \\
\text { and one for which participants felt least prepared for } \\
\text { in survivorship }\end{array}$ & $\begin{array}{l}\text { Limited sample, } \\
\text { risk of biased } \\
\text { sample and non- } \\
\text { response bias } \\
(80 \%)\end{array}$ \\
\hline
\end{tabular}




\begin{tabular}{|c|c|c|c|c|c|}
\hline Article & Method & Participants & Measures & Cognitive Results / Outcomes & $\begin{array}{c}\text { MMAT limitations } \\
\text { (score) }\end{array}$ \\
\hline $\begin{array}{l}\text { Vetsch } \\
(2018)^{52}\end{array}$ & $\begin{array}{l}\text { Cross- } \\
\text { sectional } \\
\text { interview }\end{array}$ & $\begin{array}{l}42 \text { survivors age } 15-25 \text {, } \\
\text { completed treatment } \\
\text { within past } 24 \text { months }\end{array}$ & $\begin{array}{l}\text { PAIS structured } \\
\text { interview on } \\
\text { vocational } \\
\text { function in last } 30 \\
\text { days }\end{array}$ & $\begin{array}{l}\text { - Experimenters rated cognitive or physical } \\
\text { impairments as mild to marked for } 69 \% \text { of } \\
\text { participants. } \\
\text { - Many experienced difficulty reintegrating to school or } \\
\text { work due to cognitive symptoms but } 55 \% \text { did not } \\
\text { believe their abilities were compromised. }\end{array}$ & $\begin{array}{l}\text { Limited sample, } \\
\text { risk of sampling } \\
\text { bias, biased } \\
\text { sample, and non- } \\
\text { response bias } \\
(73 \%)\end{array}$ \\
\hline \multicolumn{6}{|l|}{ Qualitative } \\
\hline $\begin{array}{l}\text { Brauer } \\
(2017)^{53}\end{array}$ & $\begin{array}{l}\text { Cross- } \\
\text { sectional } \\
\text { interview }\end{array}$ & $\begin{array}{l}18 \text { survivors age } 15-29 \\
\text { at treatment, conducted } \\
6-60 \text { months after } \\
\text { treatment }\end{array}$ & $\begin{array}{l}\text { Perspectives on } \\
\text { managing the } \\
\text { return to } \\
\text { education }\end{array}$ & $\begin{array}{l}\text { - Participants describe rushing back to school and } \\
\text { facing overwhelming cognitive demands. } \\
\text { - Cognitive difficulties are a barrier to successful, } \\
\text { sustainable re-entry }\end{array}$ & None $(100 \%)$ \\
\hline $\begin{array}{l}\text { D'Agostino } \\
(2013)^{54}\end{array}$ & $\begin{array}{l}\text { Cross- } \\
\text { sectional } \\
\text { focus group }\end{array}$ & $\begin{array}{l}22 \text { survivors age } 18-35 \\
\text { at study stratified by } \\
\text { age at diagnosis }(>=18, \\
<18) \text { and diagnosis } \\
\text { (brain cancer, other } \\
\text { cancer) }\end{array}$ & $\begin{array}{l}\text { Discussion on } \\
\text { challenges, } \\
\text { resources, and } \\
\text { program } \\
\text { recommendations }\end{array}$ & $\begin{array}{l}\text { - All age and diagnosis groups reported cognitive } \\
\text { concerns. } \\
\text { - All groups wanted access to neuropsychological } \\
\text { assessment and cognitive rehabilitation. }\end{array}$ & None $(100 \%)$ \\
\hline $\begin{array}{l}\text { Elsbernd } \\
(2018)^{55}\end{array}$ & $\begin{array}{l}\text { Cross- } \\
\text { sectional } \\
\text { interview }\end{array}$ & $\begin{array}{l}9 \text { survivors age } 15-25 \text { at } \\
\text { diagnosis and pursuing } \\
\text { education }\end{array}$ & $\begin{array}{l}\text { Perspectives on } \\
\text { managing the } \\
\text { return to } \\
\text { education }\end{array}$ & $\begin{array}{l}\text { - Participants commonly reported problems with } \\
\text { memory and concentration. } \\
\text { - Cognitive problems were "more difficult" to handle } \\
\text { because they are "invisible". }\end{array}$ & None $(100 \%)$ \\
\hline
\end{tabular}




\begin{tabular}{|c|c|c|c|c|c|}
\hline Article & Method & Participants & Measures & Cognitive Results / Outcomes & $\begin{array}{c}\text { MMAT limitations } \\
\text { (score) }\end{array}$ \\
\hline $\begin{array}{l}\text { Fauske } \\
(2019)^{56}\end{array}$ & $\begin{array}{l}\text { Cross- } \\
\text { sectional } \\
\text { interview }\end{array}$ & $\begin{array}{l}18 \text { survivors of bone } \\
\text { sarcoma ages } 18-50 \\
\text { and } 3-10 y r \text { after } \\
\text { diagnosis at study }\end{array}$ & $\begin{array}{l}\text { Psychosocial } \\
\text { challenges in } \\
\text { survivorship }\end{array}$ & $\begin{array}{l}\text { - } 17 \% \text { reported no cognitive issues and considered } \\
\text { themselves "back to normal". } \\
\text { - Other } 83 \% \text { reported varying degrees of cognitive } \\
\text { effects. } \\
\text { - Higher levels of cognitive symptoms were associated } \\
\text { with more functional and physical difficulties and } \\
\text { higher age. }\end{array}$ & None $(100 \%)$ \\
\hline $\begin{array}{l}\text { Hauken } \\
(2019)^{57}\end{array}$ & $\begin{array}{l}\text { Cross- } \\
\text { sectional } \\
\text { interview }\end{array}$ & $\begin{array}{l}20 \text { survivors age } 18-35 \\
\text { treatment completed } \\
\text { within last } 5 \text { years }\end{array}$ & $\begin{array}{l}\text { Perceived } \\
\text { outcomes from } \\
\text { cancer treatment }\end{array}$ & $\begin{array}{l}\text { - All participants reported ongoing impaired function, } \\
\text { some of whom had problems with memory and } \\
\text { concentration. }\end{array}$ & None $(100 \%)$ \\
\hline $\begin{array}{l}\text { Lopez } \\
(2019)^{58}\end{array}$ & $\begin{array}{l}\text { Cross- } \\
\text { sectional } \\
\text { interview }\end{array}$ & $\begin{array}{l}\text { Survivors of } \\
\text { gynecological cancer: } \\
\text { - } 16 \text { age } 18-39 \\
\text { - } 13 \text { age } 40+\end{array}$ & $\begin{array}{l}\text { Interviews on } \\
\text { unmet support } \\
\text { needs }\end{array}$ & $\begin{array}{l}\text { - All women reported a sense of loss of some kind. } \\
\text { - Many reported loss of role and capacity related to } \\
\text { employment, childcare, and daily activities, usually } \\
\text { related to treatment effects including "chemo-fog". }\end{array}$ & None $(100 \%)$ \\
\hline $\begin{array}{l}\text { McLoone } \\
(2011)^{59}\end{array}$ & $\begin{array}{l}\text { Cross- } \\
\text { sectional } \\
\text { interview }\end{array}$ & $\begin{array}{l}\text { - } 19 \text { survivors age } 12- \\
18 \text { at diagnosis } \\
\text { - } 36 \text { parents } \\
\text { - } 15 \text { siblings over age } \\
12\end{array}$ & $\begin{array}{l}\text { Factors related to } \\
\text { survivors' return } \\
\text { to school after } \\
\text { cancer treatment }\end{array}$ & $\begin{array}{l}\text { - Half of students had difficulty concentrating in class } \\
\text { and reduced academic performance. } \\
\text { - Two-thirds of parents reported reduced academic } \\
\text { performance. } \\
\text { - Some students had difficulty with new material, } \\
\text { especially in math. } \\
\text { - Three-quarters of families used tutoring to help } \\
\text { "catching up". }\end{array}$ & None $(100 \%)$ \\
\hline
\end{tabular}




\begin{tabular}{|c|c|c|c|c|c|}
\hline Article & Method & Participants & Measures & Cognitive Results / Outcomes & $\begin{array}{c}\text { MMAT limitations } \\
\text { (score) }\end{array}$ \\
\hline $\begin{array}{l}\text { Ruddy } \\
(2013)^{60}\end{array}$ & $\begin{array}{l}\text { Cross- } \\
\text { sectional } \\
\text { focus group }\end{array}$ & $\begin{array}{l}36 \text { female breast cancer } \\
\text { survivors age } 18-42 \text { at } \\
\text { study, avg of } 22 \text { mo post } \\
\text { diagnosis }\end{array}$ & Unmet needs & $\begin{array}{l}\text { - Many women reported substantial changes to } \\
\text { memory and challenges becoming accustomed to } \\
\text { those changes. } \\
\text { - Women desired better resources on expected } \\
\text { treatment effects. }\end{array}$ & None $(100 \%)$ \\
\hline $\begin{array}{l}\text { Stevens } \\
(2018)^{61}\end{array}$ & $\begin{array}{l}\text { Cross- } \\
\text { sectional } \\
\text { survey, } \\
\text { focus } \\
\text { group, and } \\
\text { interview }\end{array}$ & $\begin{array}{l}\text { Survivors age >=16 at } \\
\text { diagnosis, } 16-24 \text { at time } \\
\text { of study, family } \\
\text { members, } \\
\text { professionals: } \\
\text { - Survey: } 42 \text { AYAs, } 28 \\
\text { family, } 54 \text { pros } \\
\text { - Focus group: } 7 \text { AYAs } \\
\text { - Interview: } 6 \text { AYAs, } 4 \\
\text { family, } 97 \text { pros }\end{array}$ & $\begin{array}{l}\text { Unmet needs for } \\
\text { AYAs }\end{array}$ & $\begin{array}{l}\text { - AYAs needed more and better support and identified } \\
\text { a prioritized set of requirements. } \\
\text { - } 46 \% \text { of patients wanted support in dealing with brain } \\
\text { fog, but less than } 5 \% \text { were actually offered it } \\
\text { - The final recommendation related to cognition is } \\
\text { "Patients should have access to support and advice } \\
\text { regarding the management of brain fog." }\end{array}$ & None $(100 \%)$ \\
\hline
\end{tabular}

